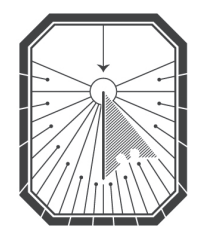

KYIV-MOHYLA

LAW \& POLITICS JOURNAL

KYIV-MOHYLA SCHOLARLY PEER-REVIEWED JOURNALS

HIV-activism in a Post-socialist State: The Case of Ukraine

Author: Tetyana Semigina

Source: Kyiv-Mohyla Law and Politics Journal 1 (2015): 113-133

Published by: National University of Kyiv-Mohyla Academy

http://kmlpj.ukma.edu.ua/ 


\title{
HIV-activism in a Post-socialist State: The Case of Ukraine
}

\author{
Tetyana Semigina
}

National University of Kyiv-Mohyla Academy,

Academy of Labor, Social Relations and Tourism

\begin{abstract}
Drawing on archival materials, in-depth qualitative interviews with current and former HIVactivists, and participant observation at HIV prevention organizations in Ukraine, I sketch the history and recent activities of HIV-activists organizations. The research allowed me to identify the role of civil society organizations in health policy processes, practices and types of HIV-activism, and challenges for this activism's development. The paper shows that major transformations have occurred in both service provision and policy practices, including the introduction of the national and regional coordination councils. These councils enforce the horizontal level of public policy, as well as changing the public's opinion regarding HIV-positive people and the measures to combat HIV. The international organizations and their beneficiaries in Ukraine are the main challengers to existing practices and the driving forces for changes in public health policy and the strengthening of participatory approaches.
\end{abstract}

Key Words: civil society, HIV-activism, health policy, Ukraine.

\section{Introduction}

In the past 25 years, major transformations of political and socio-economic systems in the countries of Soviet bloc have occurred. The existing totalitarian governments and hegemonic establishments began to crumble, and civil society became engaged into the process of local development undertaken by the former authoritarian, socialist countries in their transition towards democracy or "new democracy" as defined by Heywood. ${ }^{1}$

Ukraine is not an exception from the complex processes of this move toward democratization. Since 1991, Ukraine has been transitioning from a centrally planned economy to a market-oriented one. Ukraine also has experienced systemic crises: numerous political, economic, social and cultural problems intensified and suddenly became urgent. The Soviet Union's break-up and the resulting collapse of the state economy resulted in shortages of goods and food supplies and triggered social problems, such as unemployment, emigration, homelessness, and poverty. Accompanying these major political and social changes in Ukraine and in other post-socialist countries was a dramatic growth of juvenile delinquency, drug and alcohol misuse, mental health issues and a HIV/AIDS epidemic. The state was not able to tackle these problems, so community-based organizations and non-governmental organizations 
(NGOs) stepped in to try to foster directly participation in decision-making on matters that affected their interests.

This article's main objective is to trace the history and recent activities of HIV-activist organizations to identify the political advantages and policy and cultural challenges in their advocating for changes in health policy. More specifically, this article focuses on Ukraine's policy for combating the HIV/AIDS epidemic in Ukraine.

\section{Theoretical Framework and Methodology}

In this article, I will analyze HIV-activism in Ukraine from two perspectives: co-operational framework of civil society and a collective action. The major part of the analysis will be attempting to understand HIV-activism in the framework of contemporary civil society discourse.

Civil society is defined here as a sphere of society outside government and business. It includes a multitude of groups, organizations and associations that participate in public life and embody people's collective interests. ${ }^{2}$ These groups and networks serve as tools for citizens to voice their interests and become parties in decision-making processes.

The co-operational framework of civil society development has been recognized by researchers (among them: Alegre, ${ }^{3}$ Evans and Whitefield, ${ }^{4}$ Howell and Pearce, ${ }^{5}$ Silliman and Noble $^{6}$ ) as an integral component in addressing welfare issues. As Hermoso and Luka pointed out: "For countries transitioning from authoritarianism, the establishment of structures for more substantive democracy involves the creation of a strong state, a stable market and a vibrant civil society that can jointly work together and facilitate the development process. The cooperative and collective efforts of these sectors are essential to easing an otherwise arduous democratization process." ${ }^{7}$

2 This definition is based on the number of research works: Jean Cohen and Andrew Arato, Civil Society and Political Theory (Cambridge, MA: MIT Press, 1994); Adam B. Seligman, The Idea of Civil Society (New York: Free Press, 1992); Michael Edwards, Civil Society (Cambridge: Polity Press, 2004); Olexandr Chuvardinsky, "Civil Society in Ukraine: Establishment, Functioning and Prospective for Development" (PhD diss., Ivan Franko Lviv National University, 2008).

3 Alan G. Alegre, ed., Trends and Traditions, Challenges and Choices: A Strategic Study of Philippine NGOs (Queron: Ateneo Center for Social Policy and Public Affairs, 1996).

4 Geoffrey Evans and Stephen Whitefield, "The Politics and Economics of Democratic Commitment: Support for Democracy in Transitional Societies," British Journal of Political Science 25 (1995): 485-514.

5 Jude Howell and Lynne J. Pearce, Civil Society and Development: A Critical Exploration (London: Lynne Rienner Publishers, 2001).

6 Sidney G. Silliman and Lela Garner Noble, eds., Organizing for Democracy: NGOs, Civil Society, and the Philippine State (Honolulu, HI: University of Hawaii Press, 1998).

7 Jocelyn Clare R. Hermoso and Geanina Carmen Luca, "Civil Society's Role in Promoting Local Development in Countries in Transition: A Comparative Study of the Philippines and Romania," International Social Work 49 (2006): 320. 
Recently, a substantial debate about relations between state and civil society has emerged. Shaw ${ }^{8}$ proposes the creation of powerful civil society dominating over the two other spheres as a way of challenging power of the state and the market. The objective is to build civil society's capacity as an integral part of the effort to achieve a balance between the three sectors and to look on civil society as a vehicle for providing the infrastructure for direct democracy, particularly for countries emerging from authoritarian rule, as discussed by Tismaneanu. ${ }^{9}$ Edwards, Foley and others ${ }^{10}$ demonstrate that civil society can perform public and quasi-public functions with minimal or no involvement of the state. Other authors argue that in many countries civil society is grappling with how to address social concerns and how to devise ways in which substantive democracy can be achieved (see Blair ${ }^{11}$ ) or developed in such a way that strong and dependent relationships with the state have been established (e.g. Ljubownikow et al.). ${ }^{12}$ While Gel'man ${ }^{13}$ stipulates that in post-Soviet-political-regime-communities, NGOs merely serve as a resource for elite political actors and can influence political agenda only as allowed by these elites.

The other perspective about HIV-activism is looking at it as a "collective action problem" (concept of Ostrom ${ }^{14}$ ) aimed at building coalitions to support marginalized, socially excluded people. Thus, this article considers the profound negativity of stigma and social death associated with HIV/AIDS, traumatic experiences that facilitate HIV/AIDS activists' commitment and grassroots mobilization. ${ }^{15}$

Drawing on the works of Saul Alinsky' ${ }^{16}$ and Paulo Freire ${ }^{17}$ and the tenets of the empowerment concept by Lukes, ${ }^{18}$ this article examines community organizing programs for HIV-positive people. It also reviews ideas about the politicization of HIV-positive people

8 Martin Shaw, "Civil Society," in Encyclopedia of Violence, Peace, and Conflict, ed. Lester Kurtz (San Diego, CA: Academic Press, 200o), 269-78.

9 Vladimir Tismaneanu, "Civil Society, Pluralism, and the Future of East and Central Europe," Social Research 68 (2001): 977.

10 Bob Edwards et al., eds., Beyond Tocqueville: Civil Society and Social Capital Debate in Comparative Perspective (Tufts University, Hanover, NH: University Press of New England, 2001).

11 Harry Blair, "Jump-starting Democracy: Adult Civic Education and Democratic Participation in Three Countries," Democratization 10 (2003): 53-76.

12 Sergej Ljubownikow et al., "The State and Civil Society in Post-Soviet Russia: The Development of a Russian-style Civil Society," Progress in Development Studies 13.2 (2013): 153-66.

13 Vladimir Gel'man, "Political Opposition in Russia: A Dying Species?" Post-Soviet Affairs 21.3 (2005): 227.

14 Elinor Ostrom, Governing the Commons: The Evolution of Institutions for Collective Action (Cambridge: Cambridge University Press, 1990).

15 More information about stigma associated with HIV/AIDS can be found in Steven Robins, "From 'Rights' to 'Ritual": AIDS Activism in South Africa," American Anthropologist 108.2 (2006): 312-23.

16 Saul Alinsky, Rules for Radicals: A Pragmatic Primer for Realistic Radicals (New York: Random House, 1971).

17 Paulo Freire, Pedagogy of the Oppressed (New York: Continuum, 1986).

18 Steven Lukes, Power: A Radical View (London: Macmillan, 1974). 
(Beckmann and Bujra), ${ }^{19}$ the social inclusion of marginalized groups (Powel) ${ }^{20}$ through civil society and their ability to define the policy agenda.

This research for this article employed a mixed-methods approach that included a review of literature and secondary sources (reports, official websites etc.), field visits to seven regions of Ukraine, individual interviews and focus group discussions conducted in 2012, as well as the author's observations of activities of HIV-organizations and their media representations in social media (Facebook and Twitter). Overall, 98 interviews based on a convenience sample were conducted with the following representation: 16 informants from national organizations; 5 informants from international organizations; 32 from governmental and state structures; and 45 from NGOs. Among these 98 respondents, 77 were based in the regions; 59 were women and 40 were men. To assess perceptions of people living with HIV, 11 focus group discussions were conducted in the seven regions of Ukraine. Three focus groups involved males only (one with injection intravenous drug users (IDUs) and two with men who have sex with men); four focus groups were with females only (two with commercial sex workers); four focus groups had mixed gender. Focus group discussions were arranged with assistance from local HIV-related service providers.

This is a descriptive retrospective performance evaluation. The data were analyzed using the qualitative content analysis method. ${ }^{21}$

\section{Background Information}

\section{Nature of HIV/AIDS Epidemics in Ukraine}

According to Ukraine's Ministry of Health, the HIV/AIDS epidemic in Ukraine is the most severe in Eastern Europe and the Commonwealth of Independent States.22 Burruano and Kruglov stated that in 2009, Ukraine accounted for one in five or $21 \%$ of all cases in Eastern Europe. HIV/ AIDS places a heavy social and economic burden on the population. ${ }^{23}$ The pressure it exerts on the health system is palpable.

The majority of reported cases to date have been concentrated primarily among injection IDUs, commercial sex workers (CSWs), prisoners, "street" children, and men who have sex with men (MSM). The prevalence of HIV infection is significantly higher among IDUs than in any

19 Nadine Beckmann and Janet Bujra, “The 'Politics of the Queue': The Politicization of People Living with HIV/AIDS in Tanzania," Development and Change 41.6 (2010): 1041-64.

$20 \quad$ Fred Powell, The Politics of Social Work (London: Sage Publication, 2001).

21 John B. Williamson et al., The Research Craft: An Introduction to Social Science Methods (Boston, MA: Little, Brown, 1977).

22 Ministry of Health of Ukraine, Ukraine Harmonized AIDS Response Progress Report. Reporting Period: January 2010 - December 2011 (Kyiv, 2012).

23 Larissa Burrano and Yuriy Kruglov, "HIV/AIDS Epidemic in Eastern Europe: Recent Developments in the Russian Federation and Ukraine among Women," Gesundheitwesen 6 (2009): 277-89. 
other most at-risk groups. Research shows that all of these groups are marginal in Ukrainian society and socially excluded. ${ }^{24}$

The highest HIV prevalence rates according to the official registry system are in the Southern and Eastern regions of Ukraine; that is, in the Dnipropetrovsk, Donetsk, Odesa and Mykolaiv regions and in the city of Sevastopol and the Autonomous Republic of Crimea. ${ }^{25}$

The official statistics, however, do not reflect the real scale of the HIV/AIDS epidemic in Ukraine, including the real number of people infected with HIV. Official statistics register the number of persons tested positive for HIV and officially registered in the national registry of HIV patients. Many more Ukrainians may be unaware they are infected with HIV and therefore unable to take adequate measures to preserve their health or prevent further transmission.

\section{Public Health System in Ukraine}

The Ukrainian health care system remains practically unchanged from the Soviet times. ${ }^{26}$ Earlier studies exploiting data from reviews of Ukraine's health care system report a wide range of pressing problems, including low quality service, unsustainable financing (Karamyshev et al., Vynogradov ${ }^{27}$ ), substantial informal patient payments (Danylyv et al.), ${ }^{28}$ and an underdeveloped primary care system (Lekhan et al.). ${ }^{29}$ The data suggest that patients pay for a substantial part of their health care. WHO data indicate that private out-of-pocket expenditures are about $40.5 \%$ of total health expenditures. ${ }^{30}$ This is one of the largest shares of out-of-pocket payments in Europe and contradicts Ukraine's official "free-of-charge" policy.

Overall, the health system is centered on episodic disease management and provides less emphasis on preventive, primary and integrated health care services, which is reflected in the health system's current structure. There are separate health centers, procurement structures, and methods of care for tuberculosis (TB), HIV/AIDS, women's health, oncology, and family planning outside of the overall health system. Thus, HIV/AIDS, TB and drug addictions are often treated separately and distinctly from patients' overall health needs. Also, fragmented roles and

24 Iryna Demchenko, et al., Pokaznyk Rivnya Stygmy LZHW — Indeks Stygmy [Indicator of Level of Stigmatization of PLWA — Stigma Index] (Kyiv: Inzhiniring, 2011).

25 Ministry of Health of Ukraine, Ukraine Harmonized AIDS Response Progress Report.

26 See Irena Gryga et al., "Attitudes towards Patient Payments in Ukraine: Is there a Place for Official Patient Charges?" Zeszyty Naukowe Ochrony Zdrowia. Zdrowie Publiczne i Zarzadzanie 8.1 (2010): $69-78$.

27 Oleg Vynogradov, "State and the Problems of the Financial Resources of Health Care in Ukraine," Economika ta derzhava 12 (2007): 25-29; Dmytro Karamyshev et al., "State Policy of Public Health Service Financing in Ukraine," Derzhavne budivnytstvo 1 (2006): 37-45.

28 Andriy Danyliv et al., "Is there a Place for the Patient in the Ukrainian Health Care System? Patient Payment Policies and Investment Priorities in Health Care in Ukraine," Society and Economy 34.2 (2012): 273-91.

29 Valeriya Lekhan, et al., "Ukraine: Health system Review," Health Systems in Transition 12.8 (2010): 1-183. Danyliv et al., "Is there a Place," 273-91. 
relationships in the health sector undermine the ability of the Ministry of Health (MOH) to lead and guide the reform process. ${ }^{31}$

\section{Key Findings}

\section{The Policy of Combating HIV/AIDS in Ukraine and its General Context}

Ukraine's government recognizes the myriad challenges caused by Ukraine's HIV/AIDS epidemic and has authorized a number of its institutions to address them by adopting a multi-sector approach. However, only one-third of all allocated resources to counteract HIV/AIDS comes from Ukraine's central and local budgets. The remainder comes from the international donor community. ${ }^{32}$

Currently, HIV/AIDS is a priority issue for Ukrainian public health and social care policy. Ukraine's HIV/AIDS policy covers a broad range of interventions, including the prevention and treatment of HIV/AIS and the care and support for people living with HIV/AIDS. The interviews and literature review ${ }^{33}$ conducted for this article revealed several distinct periods in the development of HIV/AIDS policy in Ukraine:

1) Post-soviet period (first half of the 1990s) during which HIV-positive people were marginalized and stigmatized. During this period, IDUs were forced to have HIV tests, and HIV-related services were entirely within the domain of medical rather than social institutions. Whilst national legislation on HIV/AIDS met international standards, a number of studies conducted in Ukraine (Demchenko et al., Spicer et al., Zhukova) ${ }^{34}$ have shown that these standards were often violated.

2) A bureaucratically oriented period (mid-199os to 2004) was characterized by political rhetoric concerning the prevention of HIV/AIDS and treatment for people living with

Tetyana Semigina, "Polityka protudii epidemii VIL/SNIDu v Ukraini: Mizh nadiiamy ta rozcharuvanniamy," ["The Policy of Counteraction to HIV/AIDS Epidemic in Ukraine: Between Hopes and Disappointments,"] Naukovi zapysky NaUKMA: Politychni nauky 69 (2007): 22-27. UNAIDS. Comprehensive External Evaluation of the National AIDS Response in Ukraine: Consolidated Report (Kyiv, 2009). Arseniy Gutnik, "Extending Theories of NGOs: Committed HIV/AIDS Activists and Neoliberal Reforms in Ukraine," in Engaging Social Justice: Critical Studied of 21st Century Social Transformations, ed. David Fasenfest (Leiden: Brill, 20o9), 83-116; Nicole Judice et al., HIV Policy Assessment: Ukraine (Washington, DC: Futures Group, Health Policy Project, 2011); Tetyana Semigina, Policy to Combat HIV/AIDS Epidemic in Ukraine: The Role of the International Support (Kyiv: Ahenstvo Ukraina, 2008); UNAIDS. Comprehensive External Evaluation of the National AIDS Response in Ukraine: Consolidated Report (Kyiv, 2009); Viktoriya Zhukova, "Racializing Europe: Transnational and National Dimensions of Biopolitics, Health and HIV/AIDS. The case of Ukraine" (PhD diss., Budapest, CEU, 2013). Demchenko et al., Indicator of Level of Stigmatization of PLWA — Stigma Index, 4-5; Neil Spicer et al., "It's Risky to Walk in the City with Syringes': Understanding Access to HIV/AIDS Services for Injecting Drug Users in the Former Soviet Union Countries of Ukraine and Kyrgyzstan," Global Health 7 (2011); Zhukova, "Racializing Europe," 6-8. 
HIV/AIDS but was not backed up with financial support. As a result, national HIV/AIDS programs were not implemented or evaluated effectively.

3) A period of rapidly expanding HIV/AIDS programs and services (2005-2010) resulted from substantial donor support, in particular Global Fund to Fight AIDS, Tuberculosis and Malaria grants, as well as funding by around 30 donor organizations and significant funding for nongovernmental organizations to provide prevention, care and support services. ${ }^{35}$ Access to HIV/AIDS services by most at-risk groups was expanded with the countrywide introduction of methadone-based treatment in 2008. Further, by the end of 2012, the government of Ukraine provided antiretroviral therapy to almost 37,400 or $92 \%$ of the 40,350 patients receiving treatment. These achievements were possible due to the working partnerships of strong civil society organizations that provide community-based HIV prevention, care and support services and local government health providers, in particular the specialized AIDS service of 27 regional/oblasts AIDS Centers, 14 municipal AIDS centers and committed and supportive narcology and TB dispensaries. ${ }^{36}$

4) A period of advocacy and political action followed (2010-2014) during which oligarchic groups dominated politics and resulted in the strengthening of nepotic political traditions in all areas of public policy. Populism, the violation of basic human rights and corruption were the main features of Ukrainian health policy.

The HIV policy assessment conducted and published by the USAID's Health Policy Project ${ }^{37}$ in 2011 states that, despite the strong HIV policy foundation, Ukraine's HIV policy had not been fully implemented. The assessment identified the following gaps and barriers in the HIV policy's implementation: 1) a lack of detailed mechanisms, such as operational guidelines or standards, to support the implementation of HIV laws and regulations; 2) inadequate strategic planning or a lack of detail in implementation plans; 3) insufficient resources mobilized to implement the laws and regulations; and 4) a lack of awareness and acceptance of legal protections for vulnerable groups among key stakeholder groups, including law enforcement, local government, and healthcare providers. In addition, the police were abusive, irrespective of the victims' gender. The interviews identified that, overall, Ukraine's health system, with its vertical and in-patient-driven services, was one of the major barriers to improving access to and the quality of HIV-related services, achieving a reduction in HIV/AIDS morbidity and mortality and implementing HIV policy.

Stigma and discrimination is by far the biggest concern of all the most at-risk groups' representatives interviewed. Numerous IDUs and CSWs repeated harrowing stories of police brutality, corruption, and abuse. Only once during a focus group discussion was it mentioned that relationships with the police were acceptable.

In general, the HIV/AIDS epidemic had become a socially complex phenomenon that challenged the medical and social services system that had been established in the Soviet and post-Soviet periods. According to interviews with international experts, this epidemic 
accelerated with the gradual destruction of departmental isolationism of Ministry of Health of Ukraine as a policy maker and implementer for HIV/AIDS. The same can be said for the role of Ministry of Health in all policies related to health issues.

\section{A Brief Historical Account of HIV-activism in Ukraine: The Impact of Global Actors}

In Ukraine, as the results of this study indicate, few national-scaled HIV-activist organizations have local branches rooted in small mutual-support groups.

The first mutual-support groups of HIV-positive people had been organized at the end of 1990s, mainly in cities with high levels of HIV cases. Their main activities were concentrated on self-supportive psychological help and access to the free medical care declared by Ukrainian legislation. As one of the HIV-activists in his interview recalls about this time:

We had a very clear objective to get access to medical treatment, to antiviral treatment. People with HIV had united and did whatever it was possible under those circumstances. That's how the 'Network' was established.

"Network" is a short name for the charitable foundation "All-Ukrainian Network of People Living with HIV." It is one of the most powerful non-governmental public health organizations. Officially registered in 2001, the Network claims that it was established in 2000 by a few enthusiastic HIVpositive people and was involved in a number of successful campaigns. The official story of its creation posted on its website, ${ }^{38}$ however, does not stress the role of international organisations and its dependence on donor money.

Yet, the author's interviews, her analysis of websites and her observations revealed that the Network's development relied heavily on international organizations, including the Elton John AIDS Foundation (EJAF), the Global Fund to Fight AIDS, Tuberculosis and Malaria (GFATM), USAID and others.

The Network implemented a common project with the EJAF in 2001-2010. The Foundation declares that it had supported the Network because the Network was striving to become "allencompassing" toward target groups in the HIV/AIDS epidemic, including men having sex with men (MSM). As one of interviewed HIV-activist stated:

This project was rather important for setting organization. It had provided seed money to start real activities on national level.

The second important step in development of the Network relates to start in the mid-2ooos of the GFATM Program in Ukraine. This program was run by the International HIV/AIDS Alliance, which is headquartered in the UK with a technical branch in Kyiv. Initially, the GFATM Program focused on providing antiretroviral treatment, caring for HIV-positive people and offering prevention programs for the most at-risk population — drug users, commercial sex workers and

38 See The All-Ukrainian Network of People Living with HIV, "History," accessed May 1, 2014, http://www.network.org.ua/en/network/history/. 
the like. The GFATM gave funds to the Network for establishing care for HIV-positive people on the regional level. The first GFATM Program in Ukraine also undertook capacity-building activities. Then the Network became a co-recipient of the GFATM Program together with the International HIV/AIDS Alliance, a registered charitable foundation in Ukraine. ${ }^{39}$

The Network was a recipient and a co-recipient of a number of USAID Projects. For example, the HIV/AIDS Service Capacity Project (USCP) implemented in 2007-2012 focused on involving people living with HIV and representatives of the most at-risk population groups in regional and local coordination councils on HIV issues, as well as on the improvement of HIV-related services. The Project focused on capacity building, which took shape as trainings, workshops, and individualized technical assistant to selected local NGOs. These activities strengthened HIV-activists in Ukraine. The following quote from an NGO director was typical of what interviewees said about these trainings:

The training exposed me to the role media can play in promoting my NGO. After I returned, within two weeks I secured a twenty-minute weekly television spot to spread HIV/AIDS messages; I had learned from the HIV/AIDS Service Capacity Project that the public stations must devote time each week to public messages.

Now the Network has about 400 employees and provides services to around 20,000 clients. It has branches in all of Ukraine's regions. It implements a number of international projects, draws the attention of public officials and tries to influence the state decision-making process. ${ }^{40}$

Another national HIV-activist organization was established in 2004, the All-Ukrainian Charitable Foundation "Coalition of HIV-related service organizations." It brings together 77 organizations from 22 regions of Ukraine. Its announced strategy is to ensure the equal participation of NGOs in the planning, development, implementation and monitoring of HIV/ AIDS and TB control policy in Ukraine. The Coalition implements a number of international projects as a sub-recipient of the GFATM and USAID and by serving as an "umbrella" for NGOs involved in combating HIV/AIDS epidemic. ${ }^{41}$

In 2011, a new HIV-activist organization called UCAB (Charitable Foundation "Ukrainian Community Advisory Board on access to treatment in Ukraine") was established. This NGO lobbies for the interests of patients with HIV, TB and hepatitis, especially for their rights to free treatment and care. It also argues for more transparency in the implementation of public health policy. In 2013, the general meeting of UCAB changed the organization's name to Charitable Foundation "Patients of Ukraine," which made it possible to expand membership to include representatives of patients with various diseases. The partners of "Patients of Ukraine" are charitable foundations, NGOs and associations that actively protect the rights of patients in Ukraine. ${ }^{42}$

39 More details can be found here: The International HIV/AIDS Alliance in Ukraine, "About Us," accessed May 10, 2014, http://www.aidsalliance.org.ua/cgi-bin/index.cgi?url=/en/about/index.htm.

40 See: The All-Ukrainian Network of People Living with HIV, "History," accessed May 1, 2014, http://www.network.org.ua/en/network/history/.

41 See: Coalition of HIV-service Organizations, "About Us," accessed May 3, 2014, http://en.hiv.org.ua/about.

UCAB, “History," accessed May 10, 2014, http://patients.org.ua/en/about/history/. 
According to interviews, the International HIV/AIDS Alliance in Ukraine supported peerdriven prevention programs for marginalized groups and the development of such groups.

Different NGOs in Ukraine, with the support of various international donors, also fought for introducing methadone programs (substitution treatment) for IDUs. This fight led to political debates and changes in legislation. Substitution treatment is highly associated with the Westernization/Europeanization of Ukraine,${ }^{43}$ while many post-Soviet countries, including Russia, had banned this treatment.

The improvement of the policy environment to support the scale-up of methadone programs for IDUs was frustrated by the uncertain and ambivalent position of Ukrainian governmental bodies. Interviews with clients and representatives of NGOs revealed a high degree of resistance to expanding this treatment, especially by central-level authorities within the Ministry of Internal Affairs, the General Prosecutor's Office and State Security Service of Ukraine, as well as by local officers. In all the focus group discussions, opinions about police abuse and harassment against the most at-risk groups reflected these thoughts:

The police act aggressively against us. But after the "client card" was introduced, it was easier to deal with the police. Still we need more legal support, including free legal counsel.

In sum, Ukraine has a few national activist organizations in the area of HIV/AIDS, more than $15^{\circ}$ regional HIV organizations and around 30 international donors. In many cases, NGO-provided services substitute for state services. NGOs that perform activities that the state is expected to perform are channels for the implementation of the pharmaceutically oriented policy of the global actors whose focus is mostly on antiretroviral and methadone treatment.

\section{The Politicization of HIV-activism}

Despite the crucial role that NGOs in Ukraine play in the direct provision of care for HIVpositive people and in the implementation of prevention programs, they are turning into new channels of influence and control. Interviewees summarized some of the ways that civil society organizations have been strengthened, as the following comment illustrates:

Civil society has got new development that manifested in technical and professional development of HIV-related service organizations in the last five years. They are now a powerful force.

Ukrainian NGOs are fighting for the rights of HIV-positive people and against discrimination against them. This includes struggling against corruption and for greater amounts and better use of public funds for treatment. Few campaigns were successfully implemented in 2013 (for example, to get money for medical treatment for people living with TB, as more than $6 \circ \%$ of HIV-positive people are living with co-infection). Ukrainian NGOs also are struggling with out- 
of-pocket payments for treatment of patients living with HIV/AIDS, TB, drug use, hepatitis, and similar conditions.

Representatives of HIV-activist organizations are serving on national and regional coordination councils on HIV/AIDS issues. In many regions, people living with HIV have been elected as deputy chairs of such councils.

The most prominent evidence of the politicization of HIV-activism in Ukraine is found in the Euromaidan activities and the changes that followed. An analysis of websites (The AllUkrainian Network of People Living with HIV 2014, The International HIV/AIDS Alliance in Ukraine 2014), Facebook and Twitter pages ${ }^{44}$ demonstrates that, during the mass protests in Kyiv and other regions of Ukraine, HIV-activists publically expressed a clear pro-EU position and played an active role in peaceful actions. They participated in rallies, arranged their own actions and widely informed their partners about events. Indeed, some of the well-known slogans of the Euromaidan were proposed by HIV-activists (e.g. "Putin, let us go!" etc.). When the protests changed from peaceful to violent, HIV- activists (mainly from the Network of People Living with HIV/AIDS) arranged their own "field hospital" in the Euromaidan area and worked in city hospitals to serve protesters wounded on Kyiv streets.

After President Yanukovych fled and a new government was formed, HIV-activists joined working groups on the reform of health and social services, trying to draw attention not only to the needs of HIV-positive people but to the need for overall changes to the outdated postsocialist system, using HIV as a tool for political rather than pure public health interventions. For example, representatives of Coalition of HIV-related service organizations were and are active in advocating for social services reforms, including for new principles for financing local social services. Representatives of the Network of People Living with HIV/AIDS and the UCAB are lobbying for an integrated approach to health care and for anti-corruption measures within the Ministry of Health, thus challenging traditional health care delivery and public health policy.

At the same time, many initiatives and the development of HIV-activism are constrained by local political, structural and cultural factors. Interviews and focus group discussions revealed that HIV-positive people are afraid to participate in massive protest actions because of discrimination. In part, this discrimination results from the media not always being tolerant or always protecting confidential information. HIV-activists also stressed that one of challenges for political activism and political lobbying actions is the too-complicated and time-consuming conventional forms of community participation in decision-making. Nonconventional advocacy by a few radical participants has proven to be more effective.

Figure 1 presents major milestones in the history of HIV-activism in Ukraine. It shows the strong relations between the future scenarios of this activism's development and the prospect for the health care reform currently discussed by the Ministry of Health of Ukraine.

44 Facebook: All-Ukrainian Network of People Living with HIV, accessed August 1, 2014, https://www.facebook.com/All.Ukrainian.Network.of.PLWH; International HIV/AIDS Alliance in Ukraine, accessed July 27, 2014, https://www.facebook.com/pages/International-HIVAIDS-Alliance; Patients of Ukraine, accessed July 25, 2014, https://www.facebook.com/ucab.org.ua; Twitter: AllUkrainian Network of People Living with HIV, accessed July 23, 2014, https://twitter.com/network_of_ plwh. 


\section{Figure 1. Milestones In HIV-ACTIVISM IN UKraine}

Source: interviews; websites of the Network of People Living with HIV/AIDS; the International HIV/AIDS Alliance in Ukraine; UCAB

Mid 199os First self-support groups of HIV-positive people appeared

2000 The Network of People Living with HIV/AIDS was organized

2001 The Network of People Living with HIV/AIDS was officially registered and started the implementation of the common project with Elton John AIDS Foundation on national and regional levels

2004 The Global Fund Program started its implementation in Ukraine (seed money for HIV-activism and HIV-related services started to be available)

Technical office of the International HIV/AIDS Alliance started to operate in Ukraine

All-Ukrainian Coalition of HIV-related service organizations was organized

2006 The Network of People Living with HIV/AIDS received a "Red Ribbon" international award for the fight against stigma and discrimination of HIVpositive people

2007 USAID Capacity Building project started its activities aimed at improvement of political environment for HIV/AIDS programs and further development of governmental and non-governmental HIV-related services

2008 Representatives of civil organizations became members of national advisory bodies on HIV/AIDS policy issues

2010 Representatives of civil organizations became active members of regional and local advisory bodies on HIV/AIDS policy issues, were involved in elaboration of regional programs for combating HIV/AIDS epidemic

2011 The organization UCAB focusing on lobbying of rights for treatment and care was created

2013 The successful advocacy campaigns for financing of health programs were conducted

2013-2014 HIV-activists played an active role in Euromaidan activities

2014 HIV-activists joined governmental working groups on health and social services reforms 


\section{Discussions}

The lessons drawn from this study provide some useful insights of civil society development, as well as relations between global and local actors for countries emerging from authoritarianism in general.

This study proves that the HIV-activism in Ukraine is in one or the other of two categories: 1) neo-liberal (pro-rights) activism; 2) radical activism. In any case, it is based on the coalition model ${ }^{45}$ to support marginalized HIV-positive people.

The first type of activism looks at the problem of HIV/AIDS epidemic through lenses of the concept of social exclusion (Sen, Kabeer) and co-operational framework. ${ }^{46} \mathrm{HIV}$-positive people in Ukraine have low access to resources and can be regarded as marginals having "clusters of disadvantages" with limited human rights (as it defined by Jürgens and Cohen). ${ }^{47}$

Innumerable accounts of social exclusion and discrimination and the state's lack of preparedness to deal with the HIV/AIDS epidemic in Ukraine shows that the institutional discourse is still in the patronizing mode of the relationship between "the state' and 'the people." NGOs have gradually became a main welfare-provider for people living with HIV/AIDS. HIV/AIDS is different from the other areas of public health and social support for HIV/AIDs patients is different from the support to other disadvantaged groups. For instance, people living with HIV/AIDS receive more free medical and social services than other groups, such as people with disabilities and people living with many chronic diseases. ${ }^{48}$ This study demonstrates the key role of the Ukrainian NGOs and their international donors in this important change.

This process of "NGOisation" of combating HIV/AIDS epidemic in Ukraine is quite similar to those processes in countries with substantial western donor funding. Healy and Craddock stated that NGOisation supported by international organizations involved decentralization and the installation of NGOs as a channels of influence. ${ }^{49}$ This can be regarded as a post-colonial "soft imperialism" because these activities are based on the western liberal discourse of human

45 The coalition model has been described in Elinor, Governing the Commons.

46 Amartya Sen, Social Exclusion: Concept, Application, and Scrutiny. Social Development Paper (ADB, 200o); Naila Kabeer, “Poverty, Social Exclusion and the MDGs: The Challenge of 'Durable Inequalities' in the Asian Context," Institute of Development Studies Bulletin 37 (2006), 5-12; Alan G. Alegre, ed., Trends and Traditions, Challenges and Choices: A Strategic Study of Philippine NGOs; Geoffrey Evans and Stephen Whitefield, "The Politics and Economics of Democratic Commitment: Support for Democracy in Transitional Societies"; Jude Howell and Lynn J. Pearce, Civil Society and Development: A Critical Exploration; Silliman, G. Sidney and Noble, Lela Garner, eds., Organizing for Democracy: NGOs, Civil Society, and the Philippine State;

47 Ralf Jürgens and Jonathan Cohen, HIVand Human Rights: Now More Than Ever (New York: Open Society Institute, 2009).

48 Semigina, Policy to Combat HIV/AIDS Epidemic in Ukraine, 110-12.

49 Susan Craddock, City of Plague: Disease, Poverty, and Deviance in San Francisco (Minneapolis: University of Minnesota Press, 200o); Dan Healy, Homosexual Desire in Revolutionary Russia: The Regulation of Sexual and Gender Dissent (Chicago: The University of Chicago Press, 2001). 
rights and supported by the global actors of health policy through funding, technical assistance and the adoption of international standards.

NGOs in Ukraine are establishing "parallel" (doubling) structures to the state ones, which is a challenging issue. The sustainability of such services is questionable, as NGOs are heavily dependent on donors' funding and are not integrated into the national health care system. Indeed, their activities sometimes conflict with that system. As Lavalette and Ferguson have observed, civil society can be a tool to undermine state health and welfare services. ${ }^{50}$

Changes in Ukraine's national leadership (during last five years, seven ministers of health came through the government's doors) further challenges the sustainability of the policy environment for sustainable service provision. The political will to deal with the HIV/AIDS epidemic is low. It is mostly limited to declarations unaccompanied by sufficient funding for actions and measures needed to prevent HIV transmission and to care for the infected and affected.

This study demonstrates a similarity with Tuffe's findings on the difficult shift in civil society practice from service provision to an agenda of public service monitoring, social accountability and community engagement. ${ }^{51}$ At the same time, the current activities of HIV organizations in Ukraine are in line with the latest World Health Organization initiatives, including the Bamako Initiative and change@WHO52 and global social work standards. ${ }^{53}$

The political processes in Ukraine stimulated radicalism in the development of HIVactivism mainly during the Orange Revolution in 2004 and the Euromaidan in 2013-2014. HIV-activists were among those who supported both protest movements. This is consistent with the idea of Petras, which suggests that NGOs may successfully co-opt mass movements in developing countries. ${ }^{54} \mathrm{~A}$ prospective scenario for HIV-activism in Ukraine can be drawn from the ideas of Kallings and Zhukova, ${ }^{55}$ who stated that civil society has to play a more decisive role in raising awareness and pushing for changes in the status of women and removing economic and judicial obstacles to emancipation.

Ukrainian society's slow modernization process limited public opportunities to influence the course of social and political processes. Most of the population regarded themselves as passive stakeholders, including on matters of health policy. ${ }^{56}$ However, radical times provoke

$5^{\circ}$ Michael Lavalette and Iain Ferguson, "Democratic Language and Neo-liberal Practice: The Problem with Civil Society," International Social Work 50 (2007): 447-59.

$5^{1} \quad$ Thomas Tufle, "Civil Society Sphericules: Emerging Communication Platforms for Civic Engagement in Tanzania," Ethnography 15 (2014): 132-50.

$5^{2}$ World Heath Organisation, “Change@WHO: Newsletter on WHO Reform," accessed October 10, 2013, www.who.int/about/who_reform/en/index.html. Vishnthie Sewpaul, "Global Standards: Promise and Pitfalls for Re-inscribing Social Work into Civil Society," International Journal of Social Welfare 14. 3 (2005): 210-17. James Petras, “NGOs: In the Service of Imperialism," Journal of Contemporary Asia 29 (1999): 429-78.

55 Zhukova, "Racializing Europe," Lars Olaf Kallings, “The First Postmodern Pandemic: 25 Years of HIV/AIDS," Journal of Internal Medicine 263.3 (2008): 218-43.

56 Bohdan Harasimiv, Post-Communist Ukraine (Edmonton: Canadian Institute of Ukrainian Studies Press, 2002). 
radical actions. HIV-activism in Ukraine uses non-conventional activities, political lobbying and collective advocacy programs as it struggles for resources, power and new public policy values. Thus, in combating HIV/AIDS, national and local NGOs cannot be regarded as "a resource for elite political actors" (as Gel'man named NGOs in post-Soviet political regimes). ${ }^{57}$ They are more challengers than conflict-solvers, creating spaces and patterns for participatory democratic political culture.

The historical development of Ukrainian HIV-activism from providing services to political action and from conventional to non-conventional practices contrasts with comparable developments in many other countries ${ }^{58}$ where activities initially focused on anti-discriminatory policies. This is because when the HIV/AIDS problem in Ukraine became visible, the epidemic's causes were already known and supportive treatment was available.

This article shows that major transformations were undertaken both in service provision and policy practices, including that introduction of the national and regional coordination councils that enforce development of the civil society and thus the horizontal level of public policy, changing the public's opinion regarding HIV, HIV-positive people and measures to combat HIV. The international organizations and their beneficiaries in Ukraine can be considered as the main challengers to existing practices and the driving forces for these transformations. Donor funding has contradicting nature: it supports civil society development and makes it fragile at the same time. The same situation can be observed in many countries with high level of international relief programs. ${ }^{59}$

Figure 2 summarizes key features of the HIV-activism in Ukraine drawing attention of its current advantages and challenges.

The impact of international actors on the development of national approaches for combating HIV/AIDS epidemics and their contributions to the content of the relevant political programs and to the development of community-based organizations was sometimes limited by local policy actors and political traditions. This article demonstrates the complex interactions between global and local levels of policy in Ukraine. Such interactions can be explored based on non-linear processes of glocalization observed in post-socialist countries by Buzarovski. ${ }^{60}$ Thus, special attention must be given to that political and social context that influences HIV-

57 Vladimir Gel'man, "Political Opposition in Russia," 227.

$5^{8}$ See description of HIV-activism in other countries here: Dennis Altman, Power and Community. Organizational and Cultural Responses to AIDS (London: Taylor \& Francis, 1994); Steven Epstein, Impure Science: AIDS, Activism and Politics of Knowledge (Berkley: University of California Press, 1996); Lawrence Oglethorpe Gostin, The AIDS Pandemic: Complacency, Injustice and Unfulfilled Expectations (Chapel Hill: University of North Carolina Press, 2004); Ronald O. Valdiserri “Thirty Years of AIDS in America: A Story of Infinitive Hope," AIDS Education and Prevention 23 (2011): 479-94.

59 See research papers: Jonathan Garcia, "Resource Mobilization for Health Advocacy: Afro-Brazilian Religious Organizations and HIV Prevention and Control," Social Science Medicine 72 (2011): 1930-38; David McCoy et al., "Global Health Funding: How much, where it Comes from and where it Goes," Health Policy and Planning 24 (2009): 407-17.

6o Stefan Buzarovski, “Local Environmental Action Plans and the ‘Globalization' of Post-socialist Governance: The Macedonian Experience," GeoJournal 55 (2001): 557-68. 
Figure 2. STRENGTHS, ADVANTAGES AND WEAKNESSES, CHALLENGES OF HIV-ACTIVISM IN UKRAINE AS OF BEGINNING OF 2014

Source: author's reflections

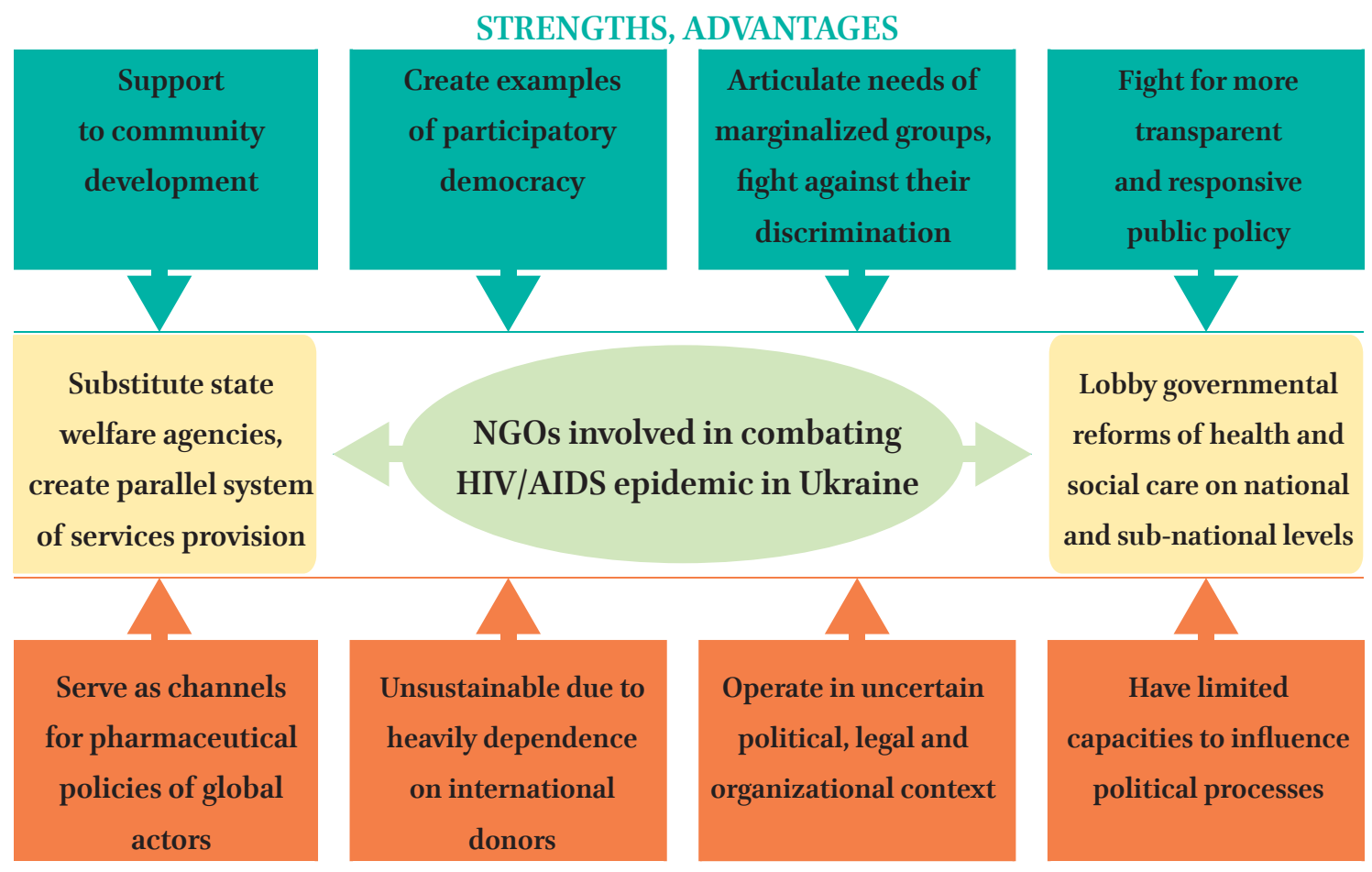

WEAKNESSES, CHALLENGES

activism as a part of civil society manifestation in Ukraine. As Kallings stresses, due to the current world order, both the UN and individual donor countries have to go through national governments, and assistance often does not reach the people. ${ }^{61}$ Therefore, even if resources are available, lack of political will and infrastructure is causing an implementation crisis. This is true for Ukraine as well.

The political, economic and social development of Ukraine as well as other post-Soviet countries argues that a certain continuum of political regimes emerged after the collapse of the USSR. These "new democracies" vary ${ }^{62}$; and the power balances between authoritarian and democratic values are different. Some countries (Latvia, Estonia, and Lithuania) were oriented on integration with the European Union and implementation of democratic values, while others (like Russia, Uzbekistan and others) preserved the authoritarian political system. Ukraine is somewhere in the middle of this spectrum having a hybrid political regime (as it was observed by Levitsky and Way in $2010^{63}$ ). However, Ukrainian civil-society organizations are working to build the structures for more substantial democracy, and sometimes these organizations began with needs-driven activities and ended up with political activism. The challenging domain of combating HIV/AIDS epidemic demonstrates such case.

$61 \quad$ Kallings, "The First Postmodern Pandemic: 25 Years of HIV/AIDS."

62 Definition by Heywood. See: Heywood, Politics.

63 Steven Levitsky and Luca Way, Competitive Authoritarianism. Hybrid Regimes after the Cold War (Cambridge: Cambridge Press, 2010). 
Despite our systematic approach, the study ran into a number of methodological problems. The non-random design of this evaluation inevitably leads to selection bias, i.e., those respondents who choose to be interviewed might differ from those who do not in terms of their attitudes and perceptions, affiliation with government/non-government structures, and sociodemographic characteristics and experience. In addition, this non-random convenient sample does not allow us to assess for the external validity of the results. Since a number of questions raised during the interviews dealt with issues that took place in the past, there is a possibility of respondent recall bias. Also, there is a known tendency among respondents to under-report socially undesirable answers and alter their responses to approximate what they perceive as the social norm (halo bias). An additional complication is that some questions called upon the respondents to assess the performance of their colleagues or people on whom they depend upon for the provision of services.

\section{Conclusions}

The HIV/AIDS epidemic in Ukraine challenged not only the public health policy and health care system, but post-Soviet political traditions as well. It questioned the non-transparent policy of the Ministry of Health, the ways of the vertical decision-making process on public health issues and exclusion of patients and representatives of risky groups from power relations.

Currently Ukraine has a few national HIV/AIDS organizations, more than 150 regional HIV organizations involved in service provision and advocating of interests of people living with HIV/AIDS. HIV-activism in Ukraine has its own unique history. It was built not from the grassroots but from the top-down. The increasing political visibility of people living with HIV/ AIDS is connected to the implementation of projects funded by around 30 international donors.

Civil society plays an increasingly greater role in the national HIV/AIDS response through service delivery and critical advocacy. HIV-activism in Ukraine combines neo-liberal (pro-rights) and radical approaches; it is based on coalition model aimed to support marginalized, socially excluded HIV-positive people. In many cases, NGOs substituted state services and performed activities expected to be done by the state, and they are not involved in dependent relations within the state. Moreover, NGOs are struggling with the common to Ukrainian health care practice of out-of-pocket payments.

The political advantages of the civil society involvement into public health policy, including combating of HIV/AIDS epidemic, are related to the fact that the Ministry of Health of Ukraine has to be more accountable, more effective public health programs, treatment and social support had been introduced. Local NGOs have stated to play more active role in solving community problems. Strengthening of civil society through micro or macro practice, building of its capacity are essential to facilitating the process of democratization within the framework of post-socialist hybrid political regime.

The dependence of many NGOs on support and financing from the Global Fund to Fight AIDS, Tuberculosis and Malaria and other international donors raises issues about their sustainability in the long-term. One more challenge is the continuing stigmatization and 
discrimination of HIV-positive people. Thus, many of them are afraid to participate in political activities because of disclosure, and this limits HIV-activism and HIV advocacy programs.

\section{Bibliography}

Alegre, Alan G., ed. Trends and Traditions, Challenges and Choices: A Strategic Study of Philippine NGOs. Queron: Ateneo Center for Social Policy and Public Affairs, 1996.

Alinsky, Saul. Rules for Radicals: A Pragmatic Primer for Realistic Radicals. New York: Random House, 1971.

Altman, Dennis. Power and Community. Organizational and Cultural Responses to AIDS. London: Taylor \& Francis, 1994.

Beckmann, Nadine and Janet Bujra. "The 'Politics of the Queue': The Politicization of People Living with HIV/AIDS in Tanzania." Development and Change 41.6 (2010): 1041-64.

Blair, Harry. "Jump-starting Democracy: Adult Civic Education and Democratic Participation in Three Countries." Democratization 10 (2003): 53-76.

Burrano, Larissa, and Yuriy Kruglov. "HIV/AIDS Epidemic in Eastern Europe: Recent Developments in the Russian Federation and Ukraine among Women." Gesundheitwesen 6 (2009): 277-89.

Buzarovski, Stefan. "Local Environmental Action Plans and the 'Globalization' of Post-socialist Governance: The Macedonian Experience.” GeoJournal 55 (2001): 557-68.

Chuvardinsky, Olexandr. "Civil Society in Ukraine: Establishment, Functioning and Prospective for Development." PhD diss., Ivan Franko Lviv National University, 2008.

Coalition of HIV-service Organizations. "About Us." Accessed May 3, 2014. http://en.hiv.org.ua/ about.

Cohen, Jean and Andrew Arato. Civil Society and Political Theory. Cambridge, MA: MIT Press, 1994.

Craddock, Susan. City of Plague: Disease, Poverty, and Deviance in San Francisco. Minneapolis: University of Minnesota Press, 2000.

Danyliv, Andriy et al. "Is there a Place for the Patient in the Ukrainian Health Care System? Patient Payment Policies and Investment Priorities in Health Care in Ukraine." Society and Economy 34.2 (2012): 273-91.

Demchenko, Iryna et al. Pokaznyk Rivnya Stygmy LZHW — Indeks Stygmy [Indicator of Level of Stigmatization of PLWA — Stigma Index]. Kyiv: Inzhiniring, 2011.

Edwards, Bob, Foley, Michael W. and Diani, Mario, eds. Beyond Tocqueville: Civil Society and Social Capital Debate in Comparative Perspective. Hanover, NH: University Press of New England, 2001.

Edwards, Michael. Civil Society. Cambridge: Polity Press, 2004.

Epstein, Steven. Impure Science: AIDS, Activism and Politics of Knowledge. Berkley: University of California Press, 1996.

Evans, Geoffrey, and Stephen Whitefield. "The Politics and Economics of Democratic Commitment: Support for Democracy in Transitional Societies." British Journal of Political Science 25 (1995): 485-514.

Freire, Paulo. Pedagogy of the Oppressed. New York: Continuum, 1986. 
Garcia, Jonathan. "Resource Mobilization for Health Advocacy: Afro-Brazilian Religious Organizations and HIV Prevention and Control." Social Science Medicine 72 (2011): 1930-38.

Gel'man, Vladimir. "Political Opposition in Russia: A Dying Species?" Post-Soviet Affairs 21.3 (2005): 226-46.

Gostin, Lawrence Oglethorpe. The AIDS Pandemic: Complacency, Injustice and Unfulfilled Expectations. Chapel Hill: University of North Carolina Press, 2004.

Gryga, Irena et al. "Attitudes towards Patient Payments in Ukraine: Is there a Place for Official Patient Charges?” Zeszyty Naukowe Ochrony Zdrowia. Zdrowie Publiczne i Zarzadzanie 8.1 (2010): 69-78.

Gutnik, Arseniy. "Extending Theories of NGOs: Committed HIV/AIDS Activists and Neoliberal Reforms in Ukraine." In Engaging Social Justice: Critical Studied of 21st Century Social Transformations, edited by David Fasenfest, 83-116. Leiden: Brill, 2009.

Harasimiv, Bohdan. Post-Communist Ukraine. Edmonton: Canadian Institute of Ukrainian Studies Press, 2002.

Healy, Dan. Homosexual Desire in Revolutionary Russia: The Regulation of Sexual and Gender Dissent. Chicago: The University of Chicago Press, 2001.

Hermoso, Jocelyn Clare R. and Luca, Geanina Carmen. "Civil Society's Role in Promoting Local Development in Countries in Transition: A Comparative Study of the Philippines and Romania." International Social Work 49 (2006): 319-32.

Heywood, Anthony. Politics. Houndmills: Palgrave MacMillan, 2002.

Howell, Jude, and J. Lynne Pearce. Civil Society and Development: A Critical Exploration. London: Lynne Rienner Publishers, 2001.

Judice, Nicole et al. HIV Policy Assessment: Ukraine. Washington, DC: Futures Group, Health Policy Project, 2011.

Jürgens, Ralf, and Jonathan Cohen. HIV and Human Rights: Now More Than Ever. New York: Open Society Institute, 2009.

Kabeer, Naila. "Poverty, Social Exclusion and the MDGs: The Challenge of 'Durable Inequalities' in the Asian Context." Institute of Development Studies Bulletin 37 (2006): 5-12.

Kallings, Lars Olaf. "The First Postmodern Pandemic: 25 years of HIV/AIDS." Journal of Internal Medicine 263.3 (2008): 218-43.

Karamyshev, Dmytro et al. "State Policy of Public Health Service Financing in Ukraine." Derzhavne budivnytstvo 1 (2006): 37-45.

Lavalette, Michael, and Iain Ferguson. "Democratic Language and Neo-liberal Practice: The Problem with Civil Society." International Social Work 5o (2007): 447-59.

Lekhan, Valeriya et al. “Ukraine: Health System Review." Health Systems in Transition 12.8 (2010): $1-183$.

Levitsky, Steven, and Lucan Way. Competitive Authoritarianism. Hybrid Regimes After the Cold War. Cambridge: Cambridge Press, 2010.

Ljubownikow, Sergej et al. "The State and Civil Society in Post-Soviet Russia: The Development of a Russian-style Civil Society." Progress in Development Studies 13.2 (2013): 153-66.

Lukes, Steven. Power: A Radical View. London: Macmillan, 1974. 
McCoy, David et al. "Global Health Funding: How much, where it Comes from and where it Goes". Health Policy and Planning 24 (2009): 407-17.

Ministry of Health of Ukraine. Ukraine Harmonized AIDS Response Progress Report. Reporting Period:January 2010 - December 2011. Kyiv, 2012.

Ostrom, Elinor. Governing the Commons: The Evolution of Institutions for Collective Action. Cambridge: Cambridge University Press, 1990.

Petras, James. "NGOs: In the Service of Imperialism." Journal of Contemporary Asia 29 (1999): 429-78.

Powell, Fred. The Politics of Social Work. London: Sage Publication, 2001.

Robins, Steven. "From 'Rights' to 'Ritual': AIDS Activism in South Africa." American Anthropologist $108.2(2006): 312-23$.

Seligman, Adam B. The Idea of Civil Society. New York: Free Press, 1992.

Semigina, Tetyana. "Polityka protudii epidemii VIL/SNIDu v Ukraini: Mizh nadiiamy ta rozcharuvanniamy." "The Policy of Counteraction to HIV/AIDS Epidemic in Ukraine: Between Hopes and Disappointments."] Naukovi zapysky NaUKMA: Politychni nauky 69 (2007): 22-27.

Semigina, Tetyana. Policy to Combat HIV/AIDS Epidemic in Ukraine: The Role of the International Support. Kyiv: Ahenstvo Ukraina, 2008.

Sen, Amartya. Social Exclusion: Concept, Application, and Scrutiny. Social Development Paper. $\mathrm{ADB}, 2000$.

Sewpaul, Vishnthie. "Global Standards: Promise and Pitfalls for Re-inscribing Social Work into Civil Society." International Journal of Social Welfare 14.3 (2005): 210-17.

Shaw, Martin. "Civil Society." In Encyclopedia of Violence, Peace, and Conflict, edited by Lester Kurtz, 269-78. San Diego, CA: Academic Press, 2000.

Silliman, G. Sidney, and Lela Garner Noble, eds. Organizing for Democracy: NGOs, Civil Society, and the Philippine State. Honolulu, HI: University of Hawaii Press, 1998.

Spicer, Neil et al. "It's Risky to Walk in the City with Syringes': Understanding Access to HIV/AIDS Services for Injecting Drug Users in the Former Soviet Union Countries of Ukraine and Kyrgyzstan." Global Health 7 (2011). Accessed May 15, 2014. http://www. globalizationandhealth.com/content/7/1/22.

The All-Ukrainian Network of People Living with HIV. "History." Accessed May 1, 2014. http:// www.network.org.ua/en/network/history/.

The International HIV/AIDS Alliance in Ukraine. "About Us." Accessed May 10, 2014. http:// www.aidsalliance.org.ua/cgi-bin/index.cgi?url=/en/about/index.htm.

Tismaneanu, Vladimir. "Civil Society, Pluralism, and the Future of East and Central Europe." Social Research 68 (2001): 977.

Tufle, Thomas. "Civil Society Sphericules: Emerging Communication Platforms for Civic Engagement in Tanzania." Ethnography 15 (2014): 132-50.

UCAB. "History." Accessed May 10, 2014. http://patients.org.ua/en/about/history/.

UNAIDS. Comprehensive External Evaluation of the National AIDS Response in Ukraine: Consolidated Report. Kyiv, 2009.

Valdiserri, Ronald O. "Thirty Years of AIDS in America: A Story of Infinitive Hope." AIDS Education and Prevention 23 (2011): 479-94. 
Vynogradov, Oleg. "State and the Problems of the Financial Resources of Health Care in Ukraine." Economika ta derzhava 12 (2007): 25-29.

Williamson, John B. et al. The Research Craft: An Introduction to Social Science Methods. Boston, MA: Little, Brown, 1977.

World Heath Organisation. "Change@WHO: Newsletter on WHO Reform." Accessed October 1O, 2013. www.who.int/about/who_reform/en/index.html.

Zhukova, Viktoriya. "Racializing Europe: Transnational and National Dimensions of Biopolitics, Health and HIV/AIDS. The Case of Ukraine." PhD diss., Central European University, 2013.

\section{(2)}

Tetyana Semigina (PhD, Dr. in Political Science) is a leading expert in Ukraine who is renowned for her deep background on HIV/AIDS. Dr. Semigina is an Associate Professor at the National University of Kyiv-Mohyla Academy and Professor of Academy of Labor, Social Relations and Tourism (Ukraine). She serves as a Secretary and a member of the Board of Directors of the International Association of Schools of Social Work. Dr. Semigina has published several reports on the status of HIV/AIDS in the Ukraine in collaboration with the London School of Hygiene and Tropical Diseases. 